\title{
THE GEOLOGY OF THE VAKKERLIEN NICKEL PROSPECT, KVIKNE, NORWAY
}

\author{
JOHN F. H. THOMPSON, FRANK NIXON and RONNY SIVERTSEN
}

\begin{abstract}
THOMPSON, JOHN F. H., NIXON, FRANK and SIVERTSEN, RONNY 1980: The geology of the Vakkerlien nickel prospect, Kvikne, Norway. Bull. Geol. Soc. Finland 52, 3-21.

The Vakkerlien nickel prospect is a small sulfide mineralized zone centrally located within a metagabbro body. The body, and a second barren metagabbro, are elongated parallel to the regional lineation. Both are compositionally zoned across the bodies from ultramafic to metagabbro. The composition of the bodies suggests that they may represent a differentiated mafic sheet, the sheet being disrupted into its present form during regional deformation. Mineral chemistry reveals a complex, possibly two phase, metamorphic history. Three sulfide types are distinguished, all containing the same sulfide phases in varying proportions. The sulfide composition suggests that the sulfides have suffered some metamorphic re-equilibration. The mineralized zone is considered to be partially in an original magmatic position with some additional concentration during deformation.

J. F. H. Thompson, Department of Geology, University of Toronto, Toronto, Ontario, M5S 1A1, Canada.

F. Nixon and R. Sivertsen, A/S Sulfidmalm, Postboks 457,

4601 Kristiansand S., Norway.
\end{abstract}

\section{Introduction}

The Vakkerlien nickel prospect is situated $6 \mathrm{~km}$ south of the village of Kvikne in central Norway (Fig. 1). The body was discovered from a reported sulfide showing by $\mathrm{A} / \mathrm{S}$ Sulfidmalm in 1975. Geophysical investigations and subsequent drilling delineated a mineralized zone over 1250 metres long with an elliptical cross-section containing approximately 400,000 metric tons of $1 \% \mathrm{Ni}$ and $0.4 \% \mathrm{Cu}$. The mineralized zone is centrally located within a similarly elongate body of metagabbro,which plunges gently southeastwards parallel to the regional lineation. The metagabbro body is cut off at its southern end by a later trondhjemitic intrusion and no major extension has been located further to the south. A second, barren metagabbro body outcrops south of the southeastern end of the main metagabbro (Fig. 2), lying parallel to the main body, with marginally larger dimensions.

The Kvikne area has had a long history of base metal exploration and exploitation from massive $\mathrm{Cu}-\mathrm{Zn}$ sulfide deposits at the old Kvikne mines (Nilson and Mukherjee, 1972) and at Røstvangen (Rui, 1973). The recently discovered occurrence of nickel sulfides in this highly deformed environment presents many problems in determining their genesis and their subsequent history. The present paper will describe the metagabbros and contained sulfide zone and postulate a model to explain their present distribution. 


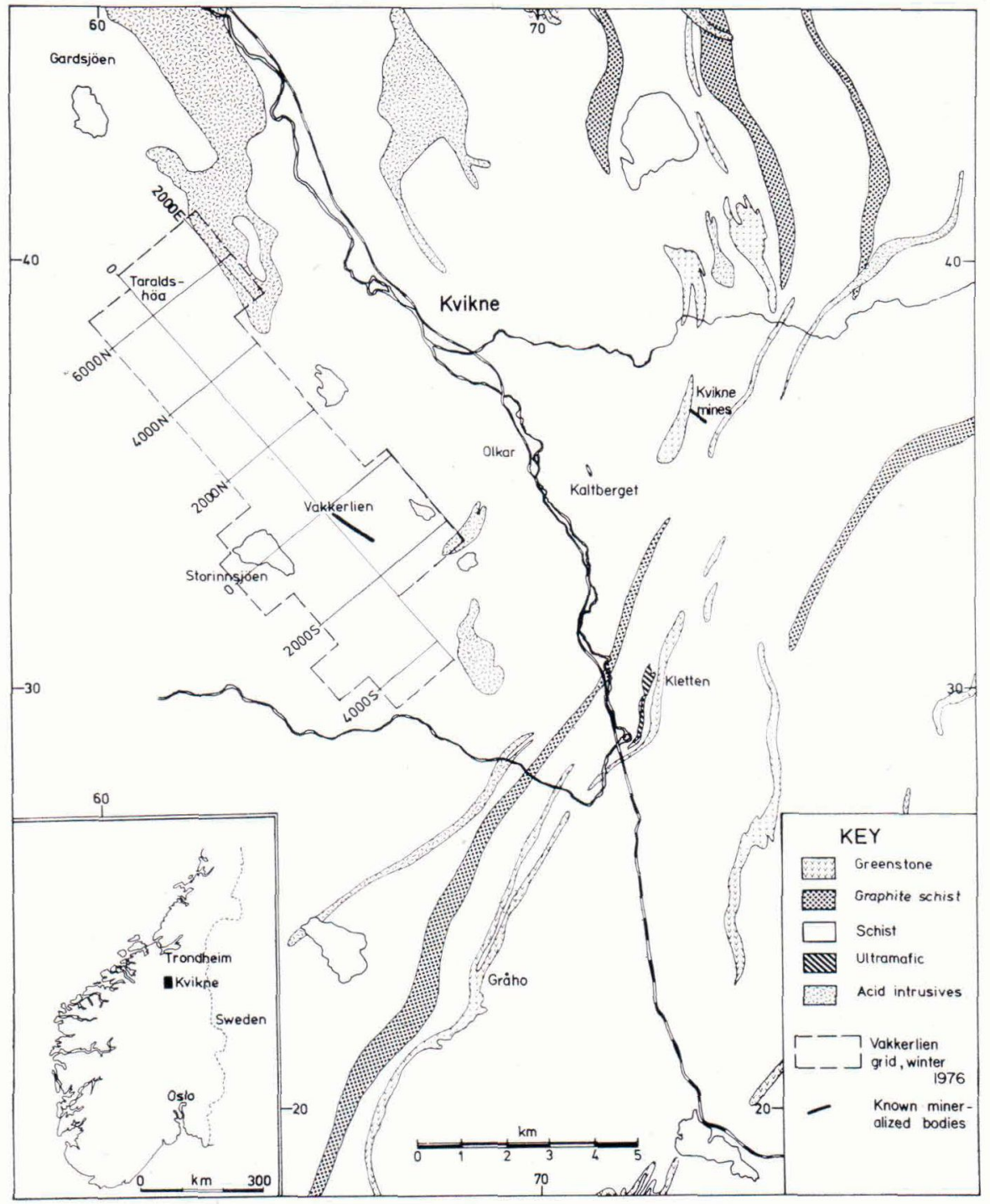

Fig. 1. Location and geology of the Kvikne area after Nilson (1974). The Vakkerlien prospect is shown.

\section{Regional geology}

Kvikne lies in the Gula group of the central Scandinavian Caledonides. The Gula group is considered to be the oldest unit of the Trondheim or 'Upper' nappe, the highest allochthonous slice in this part of the Caledonides. A variety of different structural models have been proposed for this nappe (Wegman, 1925; Wolff, 1964; Roberts, 1967;
Rui, 1971, in Rohr-Torp, 1972; Gee and Zachrisson, 1974). Recent regional tectonic models (Gee, $1975 \mathrm{a}, \mathrm{b}$, and 1978) suggest a major tectonic break between the Trondheim or 'Upper' nappe and the units to the east, based on faunal evidence characterizing two different Palaeozoic faunal provinces (Gee and Zachrisson, 1974). Internal tectonic breaks within this nappe have also been proposed, including a break between the Gula 


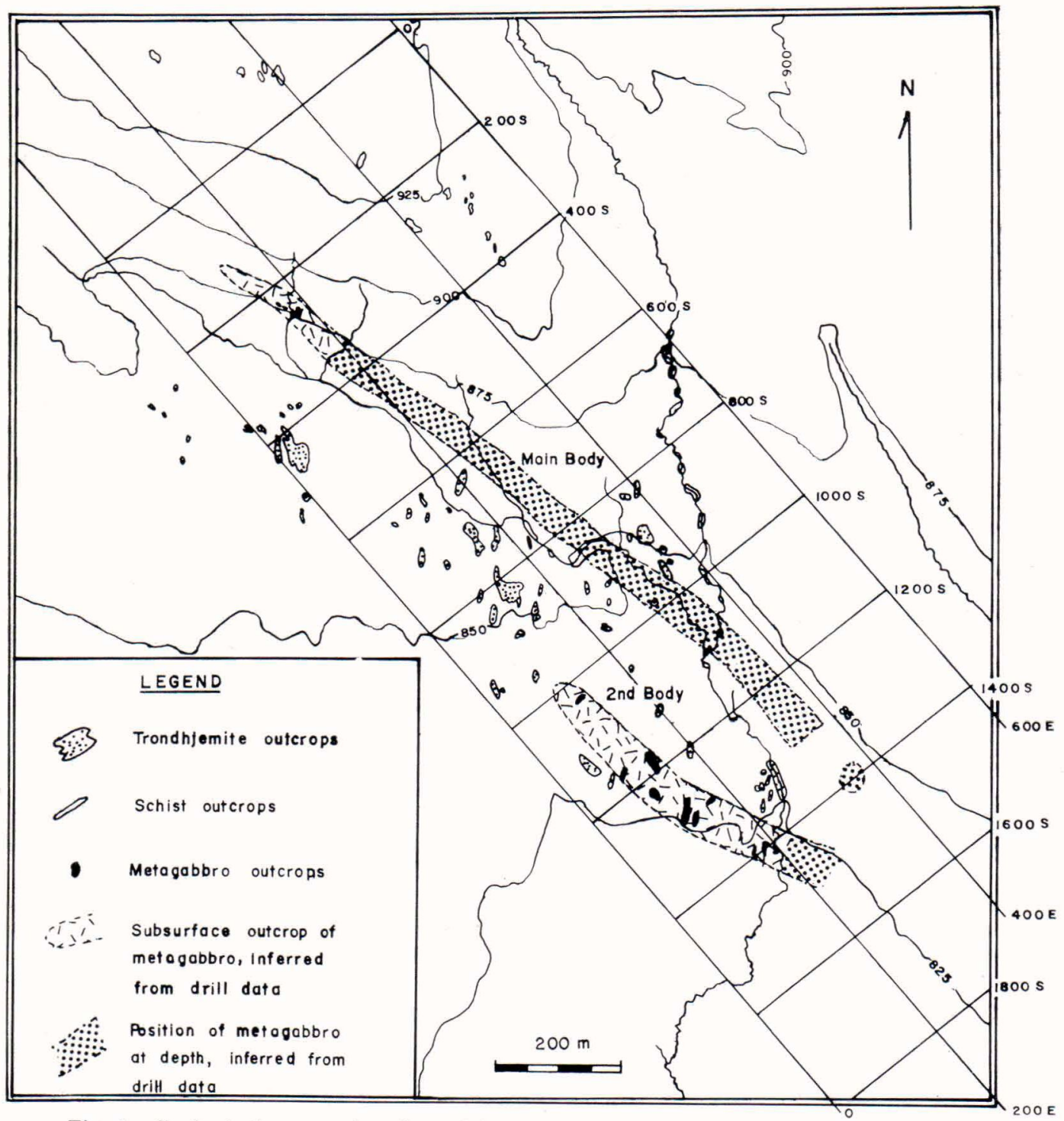

Fig. 2. Geological map in the vicinity of the Vakkerlian metagbbro bodies.

group and the overlying Støren group based on trace element geochemistry (Gale and Roberts, 1974). Such breaks present problems when correlating the Gula group in regional tectonic models. The Gula group has been postulated to be Cambrian in age, based on circumstantial evidence and the age of overlying units (Wolff, 1967). The presence of a variety of possible tectonic breaks places this age in doubt. Recent work in the Guga group, however (D. I. Rainey, pers. comm.), may clarify some of these problems, suggesting a more continuous stratigraphic sequence and confirming a Cambro-Ordivician age for the Gula group.

The Gula group consists of largely psammitic, calcareous, graphitic and pelitic schists with subordinate amphibolites and rare bodies of ultramafic and gabbroic affinities. Various studies in the Gula of Sør 


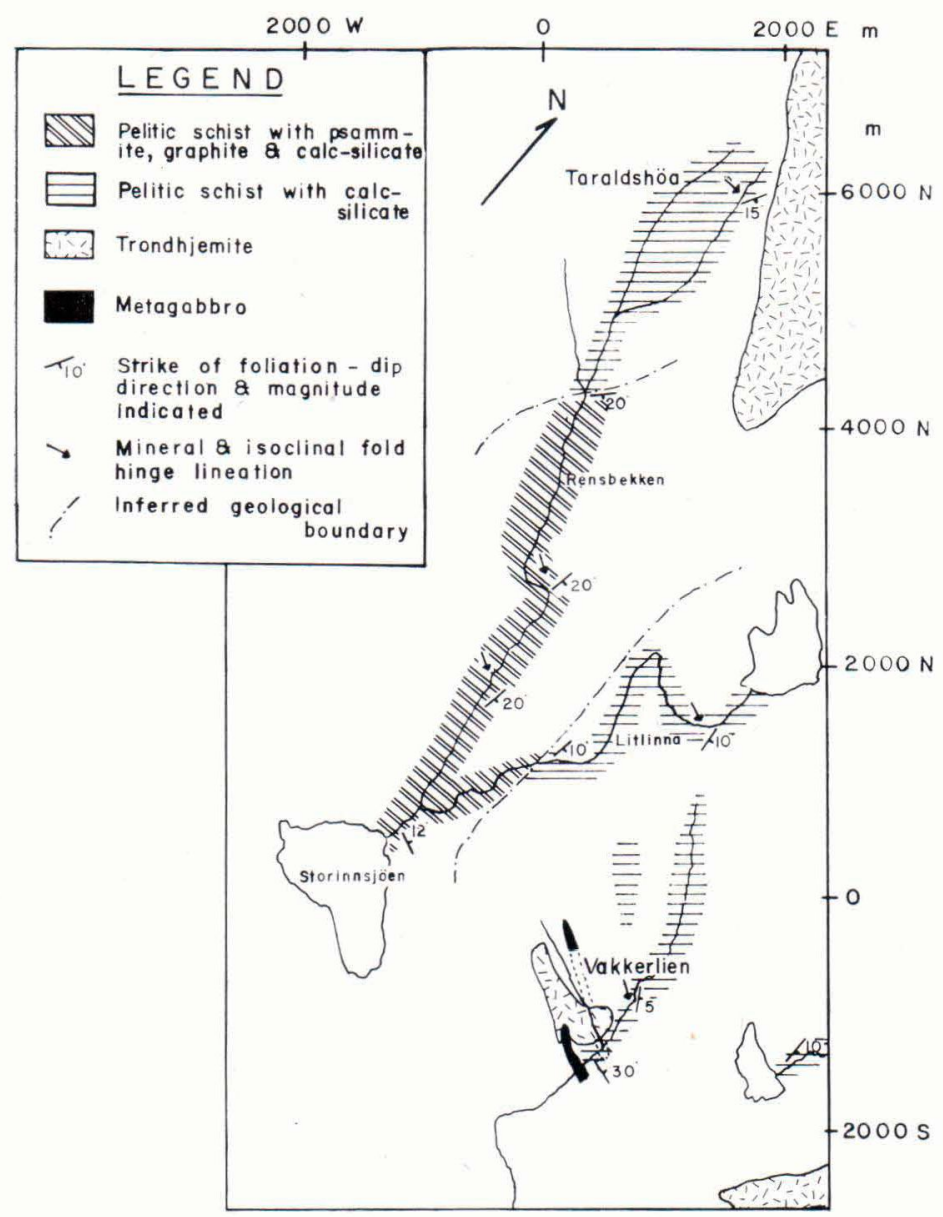

Fig. 3. Geological map of the Vakkerlien grid area, mapped largely from stream section exposure.

Trøndelag have assigned it a medium to high amphibolite grade (Nilson and Mukherjee, 1972; Guezou et al., 1972; Pinna, 1973; Rui and Bakke, 1975). Structural observations on the Gula group north of Trondheim have delineated four phases of deformation (Roberts et al., 1970), the major deformation being two isoclinal fold phases. Similar structural observations have been made south of Kvikne at Røstvangen (Rui, 1973) and at the Kvikne mines (Nilson and Mukherjee, 1972).

All the Gula group rocks are found in the Kvikne region striking parallel to the regional foliation. An attempt at establishing a stratigraphy has been made at Røstvangen
(Rui, 1973), although repetition by isoclinal folding prevents establishing any uniform stratigraphy regionally. Fig. 1 illustrates some of the major lithological units in the vicinity of Kvikne, although recent mapping of a localized portion of this area indicates that amphibolites and graphitic schists are more widespread than indicated.

Mapping of available exposure, essentially limited to stream sections, within the Vakkerlien grid area reveals two generalized units as shown in Fig. 3. In the immediate vicinity of the Vakkerlien metagabbro bodies, banded and laminated pelitic and calc-silicate schists predominate with minor psammitic bands. The contact mapped on the Litlinna 
stream section northeast of Storinsjøen is an arbitrary one based on an increase in psammitic and graphitic bands. The complex interbanding of different rocks and the resultant chemical inhomogeneity have resulted in reactions occurring between layers during metamorphism and, consequently, no uniform pelitic or calc-silicate system can be found to define metamorphic grade.

Felsic intrusions, largely trondhjemites, with subordinate diorites and pegmatites, are common throughout the region (Fig. 1). Their form varies from large masses to minor bodies and concordant and discordant sheets. A range of cross-cutting relationships indicates a complex sequence of intrusion, although all the bodies in the Vakkerlien grid area (Figs. 2 and 3 ) postdate the major isoclinal folding events.

\section{The Vakkerlien metagabbro bodies}

Detailed observations on drill core intersecting the main Vakkerlien metagabbro indicated that considerable lithological variation is present. Petrographically and geochemically the rocks can be divided into two arbitrary types, metagabbroic and ultramafic, with alteration and deformation producing further variation. Similar rock types were noted from limited drill intersections in the second body, with some additional variation.

\section{Petrography}

Approximately $50 \%$ of the main body consists of rocks arbitrarily termed metagabbro. These vary from coarse metagabbro, generally lacking any mineral foliation, to highly sheared and altered metagabbro. The coarse metagabbro consists of plagioclase and amphibole in varying but commonly equal proportions. Accessory minerals include quartz, calcite, biotite, chlorite clinozoisite, sphene, rutile, sericite and sulfides. Individual strained amphibole and plagioclase grains are common. Increased shearing produces a mineral foliation, some segregation and a highly recrystallized granoblastic texture. The fundamental mineralogy remains similar, although the amounts of chlorite, clinozoisite, quartz and calcite, and locally biotite, increase. Similar coarse and sheared metagabbro occur in the second metagabbro body, although amphibole porphyroblasts, up to 1 $\mathrm{cm}$. across, are common in unsheared variants of this unit.

Ultramafic rock types also vary from largely undeformed to highly sheared and altered. Coarse ultramafic is composed of amphibole and chlorite in highly variable proportions. Commonly amphibole occurs as porphyroblasts, up to $0.8 \mathrm{~mm}$. across, in a groundmass of matted acicular chlorite. Accessory minerals include talc, carbonate and biotite in the more chlorite-rich samples, and quartz (commonly intergrown with jagged amphibole grains) biotite, plagioclase, sphene and rutile in more amphibole-rich samples. Shearing results in a clear amphibole and chlorite foliation and a dramatic increase in the biotite content, varying from $20 \%$ homogeneously distributed in weakly foliated ultramafic to $80 \%$ in prominent confined shear zones. Similar rock types were noted in the second body with the more common presence of large amphibole porphyroblasts. Talc, carbonate and apatite bearing ultramafic rocks also appeared to be more common in the second body.

The mineralogy of the rock types above reflects the whole rock composition with the additional alteration being most apparent in sheared areas. Although the division into metagabbro and ultramafic is quite arbitrary, intermediate rock types are rare.

\section{Rock type distribution}

The distribution of rock types in any one drill hole is exceedingly complex. Various 


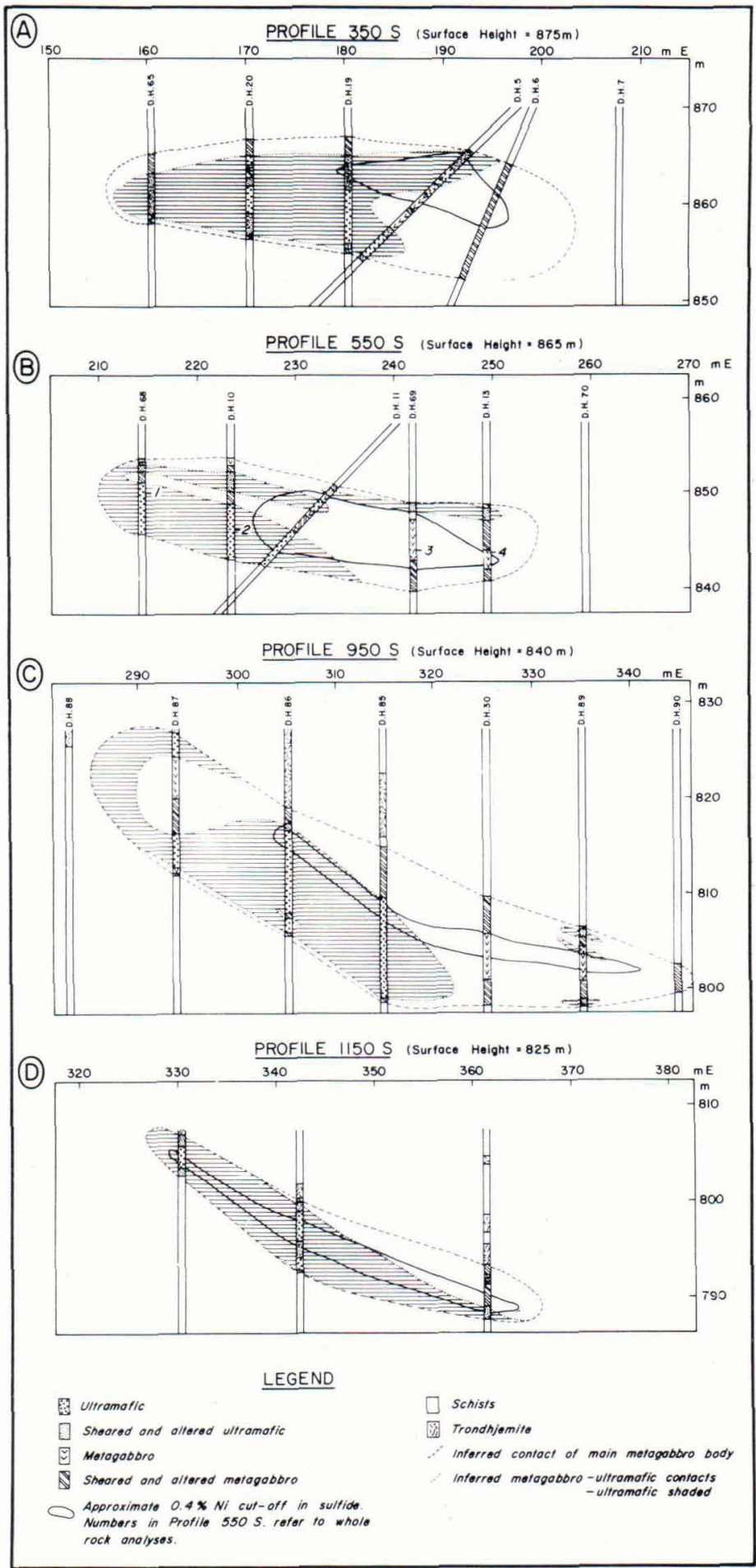

Fig. 4. Four profile cross-sections through the main metagabbro body. rocks appear to enclose other rocks with zones of deformation and alteration most apparent at the contacts. If, however, the rock types are grouped into essentially ultramafic and metagabbroic types, a simple zonation emerges across the main metagabbro. This zonation is shown in four profile sections (Fig. 4), with ultramafics clearly dominating the southwest side of the body and metagabbro on the northeast side. Only one profile was drilled across the second metagabbro (Fig. 5), which may not be representative. Within the limited observations, however, a similar zonation to that of the main body is exhibited.

\section{Petrochemistry}

The major elements of the representative rock types have been analyzed at the University of Toronto by XRF (Siemens) method using a sample fused with lithium tetraborate in the technique described by Norrish and Hutton (1969). FeO was determined by potassium dichromate titration and loss on ignition was determined by heating in a furnace with correction for the oxidation of FeO. Each analysis was determined in duplicate. 
Table 1. Whole rock analyses and CIPW norms of ten characteristic main body samples.

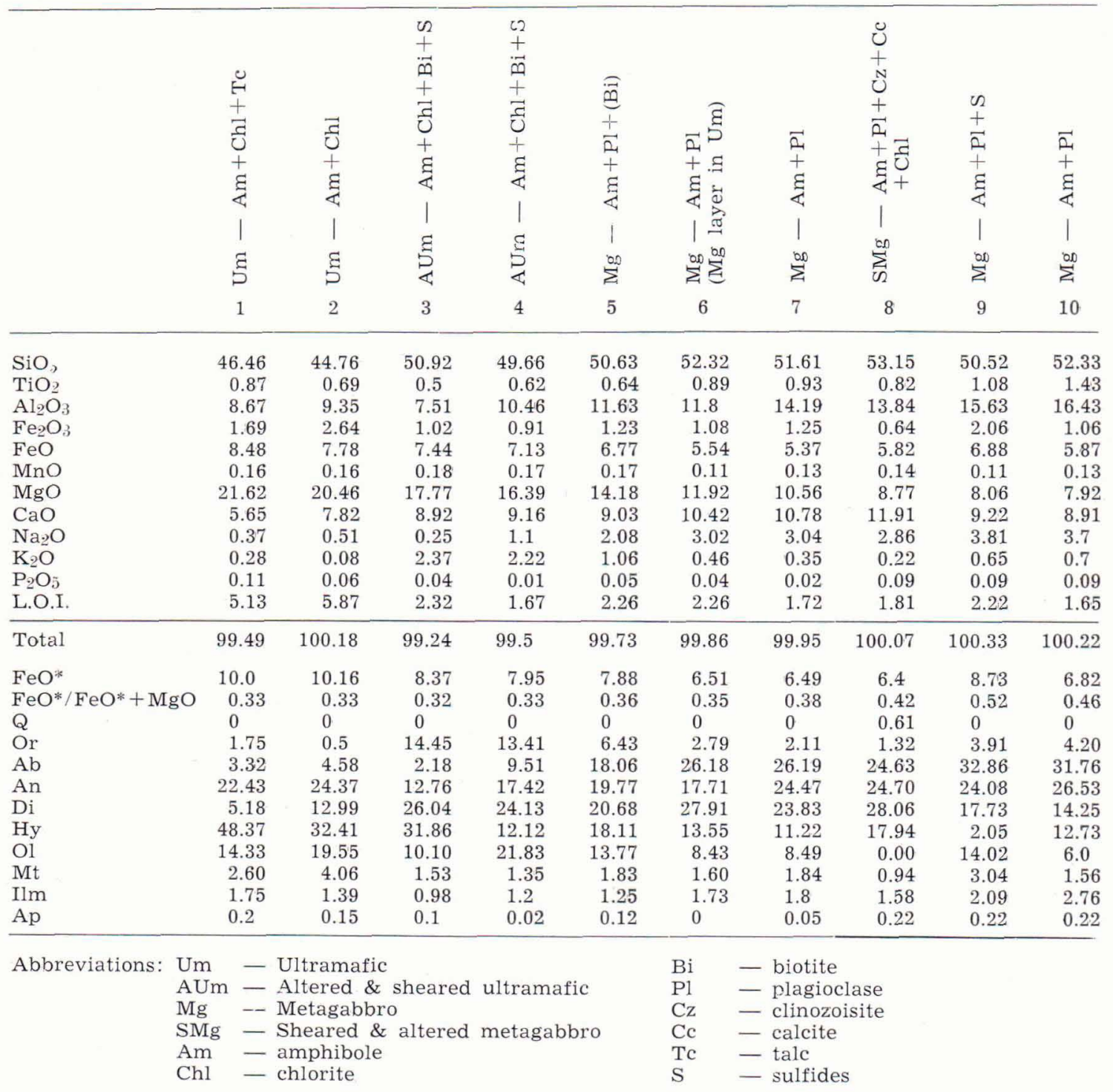

Ten analyses of representative rock types from the main body are given in Table 1 in order of decreasing MgO. The rock types, as defined by the mineralogy and the state of deformation, are also given. Table 2 gives four analyses across profile $550 \mathrm{~S}$ and five analyses across the second body, profile 1400 $\mathrm{S}$, with sample locations indicated by the numbers on Figs. 4 and 5 respectively.
With decreasing $\mathrm{MgO}$ content of the rocks, the following observations may be made:

1. $\mathrm{Al}_{2} \mathrm{O}_{3}$ and $\mathrm{Na}_{2} \mathrm{O}$ increase fairly uniformly

2. $\mathrm{SiO}_{2}$ and $\mathrm{CaO}$ show an erratic and variable increase

3. $\mathrm{TiO}_{2}$ rises gently

4. $\mathrm{Fe}_{2} \mathrm{O}_{3}$ and total iron are extremely erratic

5. $\mathrm{K}_{2} \mathrm{O}$ is generally low with sporadic higher values, particularly at low $\mathrm{MgO}$ contents. 


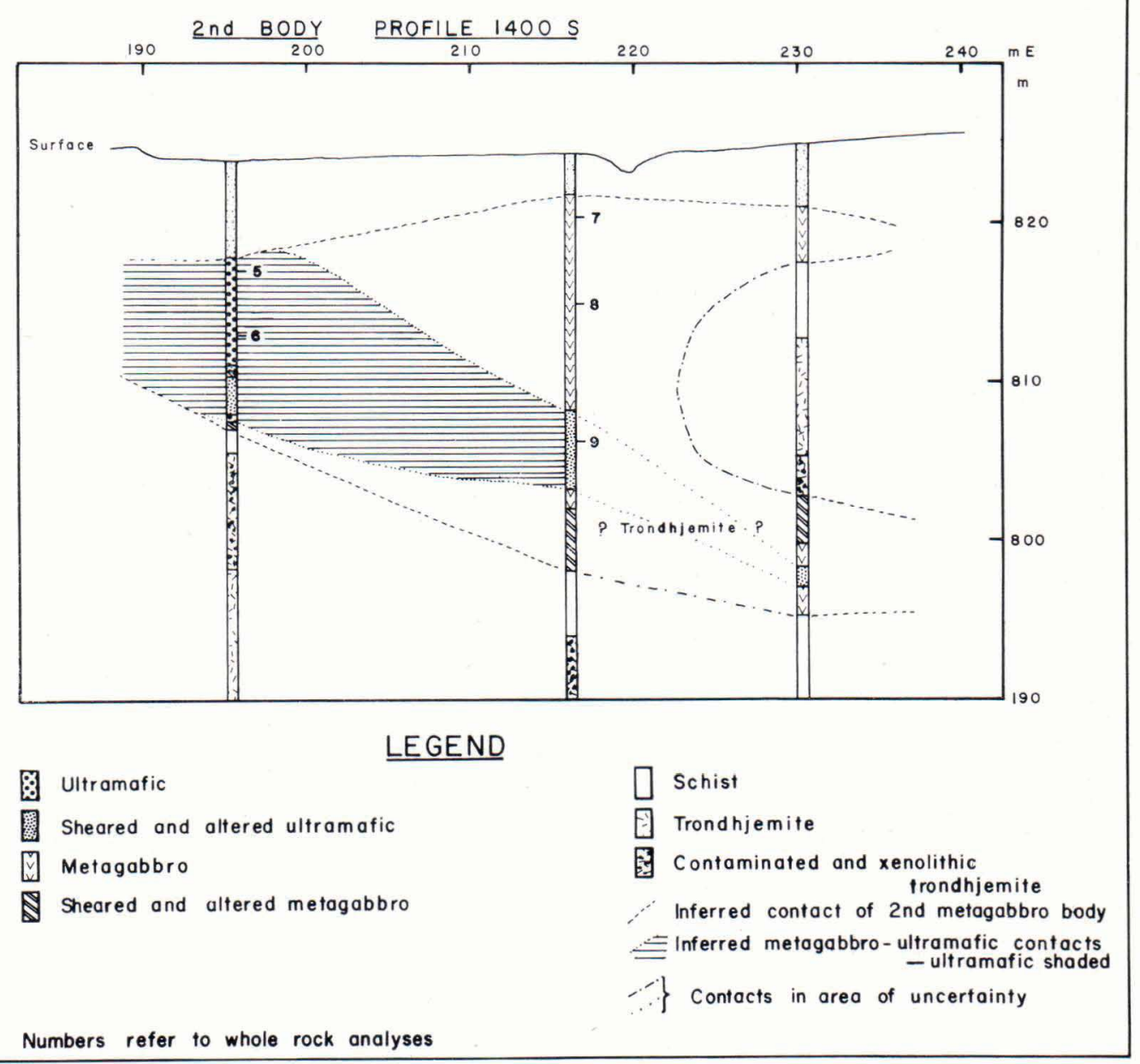

Fig. 5. Cross-section through the second body.

Some of this behaviour clearly relates to alteration and metamorphism. The presence of numerous small quartz veins, occasional calcite veins, sulfide stringers and biotite-rich shear zones can account for the erratic behaviour of $\mathrm{SiO}_{2}, \mathrm{CaO}, \mathrm{FeO}^{*}$ and $\mathrm{K}_{2} \mathrm{O}$. A plot of the analyses on an AFM diagram (Fig. 6) shows a fairly regular variation even allowing for some of the alteration effects. The trend is compared to trends from other igneous complexes, indicating the weak iron enrichment of the Vakkerlien rocks with closer similarities to a 'calc-alkaline' trend. The field of Gula metavolcanics is shown after Nilson (1974), suggesting a somewhat different chemical trend. Consideration of the regional metamorphism and local alteration effects, however, means that the use of this diagram to discriminate the petrogenetic affiliations of these rocks is subject to some uncertainty.

Nilson (1974) suggests that this and other mafic and ultramafic bodies of the Gula group represent intracrustal cumulates related to the Gula metavolcanics. The presence of numerous schist inclusions within the metagabbro bodies indicate that the Vakkerlien bodies were intruded as a liquid and 
Table 2. Whole rock analyses and CIPW norms of samples from Profiles 550S, Main body and 1400S, Second body. Location of these samples are shown in Figs. 4 and 5 respectively.

\begin{tabular}{|c|c|c|c|c|c|c|c|c|c|}
\hline & \multicolumn{4}{|c|}{ PROFILE $550 \mathrm{~S}$} & \multicolumn{5}{|c|}{ 2nd BODY - PROFILE $1400 \mathrm{~S}$} \\
\hline & 1 & 2 & 3 & 4 & 5 & 6 & 7 & 8 & 9 \\
\hline $\mathrm{SiO}_{2}$ & 46.67 & 44.05 & 50.0 & 50.81 & 39.45 & 48.38 & 50.94 & 53.13 & 50.11 \\
\hline $\mathrm{TiO}_{2}$ & 0.47 & 0.56 & 0.5 & 0.64 & 0.29 & 0.79 & 0.92 & 1.03 & 1.06 \\
\hline $\mathrm{Al}_{2} \mathrm{O}_{3}$ & 8.11 & 7.75 & 13.12 & 14.96 & 6.85 & 7.11 & 15.18 & 14.73 & 11.74 \\
\hline $\mathrm{Fe}_{2} \mathrm{O}_{3}$ & 2.4 & 1.6 & 2.3 & 0.94 & 1.11 & 1.29 & 1.21 & 1.03 & 1.29 \\
\hline $\mathrm{FeO}$ & 7.8 & 8.12 & 6.7 & 5.44 & 8.04 & 7.93 & 5.86 & 6.5 & 7.37 \\
\hline $\mathrm{MnO}$ & 0.15 & 0.16 & 0.12 & 0.13 & 0.11 & 0.16 & 0.13 & 0.13 & 0.15 \\
\hline $\mathrm{MgO}$ & 22.99 & 23.91 & 11.21 & 11.83 & 24.23 & 21.39 & 10.45 & 7.99 & 14.71 \\
\hline $\mathrm{CaO}$ & 4.47 & 4.13 & 10.19 & 9.94 & 5.37 & 6.36 & 10.45 & 9.93 & 8.16 \\
\hline $\mathrm{Na}_{2} \mathrm{O}$ & 0.39 & 0.26 & 2.32 & 2.72 & 0.02 & 0.25 & 2.77 & 3.0 & 1.95 \\
\hline $\mathrm{K}_{2} \mathrm{O}$ & 0.2 & 0.01 & 0.67 & 0.53 & 0.8 & 1.99 & 0.96 & 0.29 & 1.18 \\
\hline $\mathrm{P}_{2} \mathrm{O}_{5}$ & 0.17 & 0.17 & 0.07 & 0.06 & 0.1 & 0.11 & 0.04 & 0.17 & 0.13 \\
\hline Total & 100.55 & 99.17 & 99.22 & 99.99 & 99.53 & 99.85 & 100.06 & 100.15 & 100.67 \\
\hline $\mathrm{FeO}^{*}$ & 9.96 & 9.56 & 8.77 & 6.29 & 9.04 & 9.09 & 6.95 & 8.02 & 8.53 \\
\hline $\mathrm{FeO}^{*} / \mathrm{FeO}^{*}+\mathrm{MgO}$ & 0.3 & 0.29 & 0.44 & 0.35 & 0.27 & 0.3 & 0.4 & 0.5 & 0.37 \\
\hline $\mathrm{Q}$ & 0 & 0 & 0 & 0 & 0 & 0 & 0 & 2.43 & 0 \\
\hline Or & 1.26 & 0.07 & 4.07 & 3.2 & 5.47 & 12.28 & 5.74 & 1.75 & 7.13 \\
\hline $\mathrm{Ab}$ & 3.52 & 2.42 & 20.20 & 23.48 & 0.20 & 2.21 & 23.70 & 25.92 & 16.86 \\
\hline An & 21.09 & 21.36 & 24.08 & 27.6 & 18.80 & 12.95 & 26.44 & 26.41 & 20.2 \\
\hline $\mathrm{Di}$ & 1.08 & 0 & 22.03 & 17.83 & 8.97 & 15.31 & 20.59 & 18.40 & 16.21 \\
\hline $\mathrm{Hy}$ & 55.13 & 51.40 & 16.86 & 12.47 & 20.04 & 33.62 & 6.82 & 21.24 & 20.99 \\
\hline $\mathrm{Ol}$ & 12.84 & 20.35 & 8.19 & 12.65 & 43.75 & 19.84 & 13.08 & 0 & 14.30 \\
\hline $\mathrm{Mt}$ & 3.71 & 2.56 & 3.43 & 1.39 & 1.86 & 1.95 & 1.77 & 1.52 & 1.91 \\
\hline $\mathrm{Ilm}$ & 0.95 & 1.17 & 0.98 & 1.24 & 0.64 & 1.57 & 1.77 & 2.0 & 2.06 \\
\hline C & 0 & 0.23 & 0 & 0 & 0 & 0 & 0 & 0 & 0 \\
\hline Ap & 0.43 & 0.44 & 0.17 & 0.1 & 0.27 & 0.27 & 0.10 & 0.4 & 0.31 \\
\hline
\end{tabular}

probably differentiated in place. Whole rock chemistry, however, fails to support the genetic connection suggested by Nilson, and

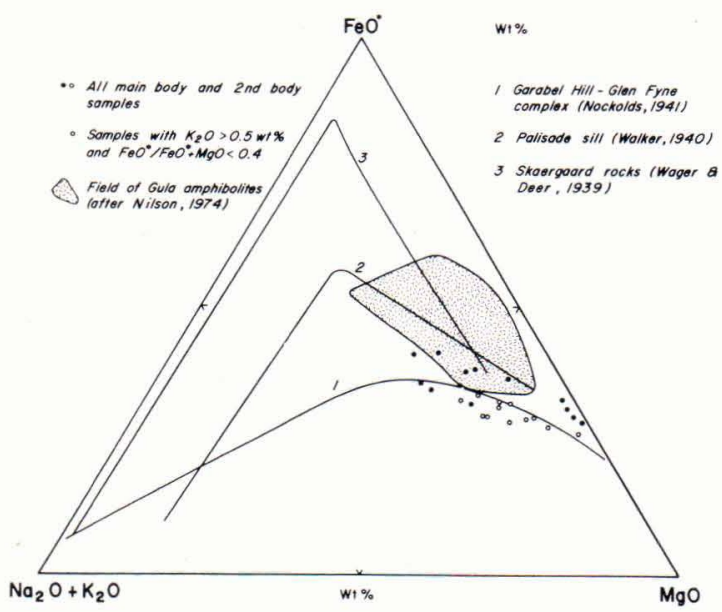

Fig. 6. AFM - diagram of Vakkerlien rocks with the field of Gula metavolcanics and some fractionation trends shown for comparison. the lack of metavolcanics within $7 \mathrm{~km}$. of Vakkerlien casts further doubt on his suggestion. It is our opinion that the actual relationship of Vakkerlien to the Gula metavolcanics, both with respect to timing and genesis, remains uncertain.

\section{Mineral chemistry}

Microprobe analyses of minerals were performed on the University of Toronto ARL microprobe using energy dispersive procedures with a $15 \mathrm{kV}$ incident beam and a beam current normalized to 3000 c.p.s Counting times were varied for each mineral from 50 to 150 seconds live time. A series of natural standards was used, and computer reduction and correction was carried out using an adapted version of the Smith and Gold (University of Alberta) program. 
Table 3. Microprobe analyses of zoned amphiboles from a variety of Vakkerlien rock types.

\begin{tabular}{|c|c|c|c|c|c|c|c|c|c|c|}
\hline \multirow{2}{*}{ Sample } & \multicolumn{2}{|c|}{$76 \mathrm{Va} 5$} & \multicolumn{2}{|c|}{$77 \mathrm{Vpl}$} & \multicolumn{2}{|c|}{ 76Vs98 } & \multicolumn{2}{|c|}{$76 \mathrm{Val}$} & \multicolumn{2}{|c|}{$77 \mathrm{~V} 2 \mathrm{~S} 6$} \\
\hline & $\mathrm{C}$ & $\mathrm{M}$ & $\mathrm{C}$ & $\mathrm{M}$ & $\mathrm{C}$ & $\mathrm{MI}$ & $\mathrm{C}$ & $\mathrm{M}$ & $\mathrm{C}$ & M \\
\hline $\mathrm{SiO}_{2}$ & 42.45 & 48.81 & 46.65 & 50.99 & 49.29 & 51.7 & 49.82 & 55.24 & 48.4 & 54.61 \\
\hline $\mathrm{Al}_{2} \mathrm{O}_{3}$ & 16.12 & 9.53 & 11.55 & 7.61 & 8.56 & 5.97 & 8.3 & 2.17 & 7.68 & 2.9 \\
\hline $\mathrm{TiO}_{2}$ & 1.63 & 0.44 & 1.07 & 0.4 & 1.09 & 0.33 & 0.42 & - & 0.55 & 0.2 \\
\hline $\mathrm{Cr}_{2} \mathrm{O}_{3}$ & 0.12 & - & - & 0.1 & - & 0.13 & - & - & 0.13 & 0.14 \\
\hline $\mathrm{FeO}$ & 12.15 & 10.43 & 10.35 & 9.72 & 9.6 & 8.45 & 8.7 & 7.04 & 9.1 & 5.98 \\
\hline $\mathrm{MgO}$ & 11.09 & 15.17 & 14.21 & 16.44 & 15.79 & 17.26 & 16.83 & 20.04 & 17.72 & 20.94 \\
\hline $\mathrm{MnO}$ & - & 0.21 & - & 0.21 & 0.22 & 0.2 & 0.13 & - & 0.1 & - \\
\hline $\mathrm{CoO}$ & 0.12 & 0.13 & 0.1 & 0.14 & 0.17 & 0.18 & 0.15 & - & 0.12 & 0.13 \\
\hline $\mathrm{CaO}$ & 11.81 & 11.99 & 12.04 & 12.1 & 12.19 & 12.63 & 11.83 & 12.57 & 10.26 & 12.18 \\
\hline $\mathrm{Na}_{2} \mathrm{O}$ & 1.74 & 0.89 & 0.95 & 0.47 & - & - & 1.04 & - & 1.11 & - \\
\hline $\mathrm{K}_{2} \mathrm{O}$ & 0.57 & - & 0.36 & - & 0.26 & - & 0.19 & - & 1.23 & - \\
\hline Sum & 97.78 & 97.59 & 97.27 & 98.2 & 97.18 & 97.85 & 97.41 & 97.37 & 96.4 & 97.08 \\
\hline \multicolumn{11}{|l|}{$\mathrm{At}^{0} / 0$} \\
\hline $\mathrm{Si}$ & 6.198 & 6.992 & 6.73 & 7.21 & 7.062 & 7.292 & 7.101 & 7.773 & 7.024 & 7.642 \\
\hline $\mathrm{Al}$ & 2.775 & 1.609 & 1.964 & 1.269 & 1.445 & 1.159 & 1.395 & 0.358 & 1.314 & 0.479 \\
\hline $\mathrm{Ti}$ & 0.179 & 0.048 & 0.116 & 0.042 & 0.118 & 0.035 & 0.045 & - & 0.06 & 0.021 \\
\hline $\mathrm{Cr}$ & 0.013 & - & - & 0.012 & - & 0.014 & - & - & 0.015 & 0.015 \\
\hline $\mathrm{Fe}$ & 1.484 & 1.25 & 1.249 & 1.15 & 1.15 & 0.997 & 1.037 & 0.824 & 1.104 & 0.7 \\
\hline $\mathrm{Mg}$ & 2.413 & 3.239 & 3.056 & 3.466 & 3.373 & 3.628 & 3.576 & 4.182 & 3.833 & 4.369 \\
\hline $\mathrm{Mn}$ & - & 0.025 & - & 0.025 & 0.027 & 0.024 & 0.016 & - & 0.013 & - \\
\hline $\mathrm{Co}$ & 0.014 & 0.015 & 0.012 & 0.016 & 0.019 & 0.02 & 0.017 & - & 0.013 & 0.014 \\
\hline $\mathrm{Ca}$ & 1.848 & 1.84 & 1.86 & 1.833 & 1.871 & 1.909 & 1.807 & 1.886 & 1.596 & 1.827 \\
\hline $\mathrm{Na}$ & 0.492 & 0.246 & 0.265 & 0.129 & - & - & 0.288 & - & 0.314 & - \\
\hline $\mathrm{K}$ & 0.106 & - & 0.066 & - & 0.048 & - & 0.035 & - & 0.227 & - \\
\hline $\mathrm{O}$ & 23 & 23 & 23 & 23 & 23 & 23 & 23 & 23 & 23 & 23 \\
\hline CATSUM & 15.51 & 15.25 & 15.32 & 15.15 & 15.07 & 15.1 & 15.30 & 15.02 & 15.54 & 15.06 \\
\hline Mg* & 0.62 & 0.72 & 0.71 & 0.75 & 0.74 & 0.78 & 0.77 & 0.83 & 0.77 & 0.86 \\
\hline $\mathrm{MgO}^{*}$ & 0.48 & 0.59 & 0.58 & 0.62 & 0.62 & 0.67 & 0.66 & 0.74 & 0.66 & 0.78 \\
\hline $\mathrm{Al} I \mathrm{IV}$ & 1.802 & 1.008 & 1.27 & 0.79 & 0.938 & 0.708 & 0.899 & 0.227 & 0.976 & 0.358 \\
\hline $\mathrm{AlVI}$ & 0.973 & 0.601 & 0.694 & 0.479 & 0.507 & 0.451 & 0.496 & 0.131 & 0.338 & 0.121 \\
\hline $\mathrm{Na}+\mathrm{K}$ & 0.598 & 0.246 & 0.331 & 0.129 & 0.048 & - & 0.323 & - & 0.541 & - \\
\hline
\end{tabular}

$\mathrm{Mg} *=\mathrm{Mg} / \mathrm{Mg}+\mathrm{Fe}+\mathrm{Mn}$

$\mathrm{MgO} *=\mathrm{MgO} / \mathrm{MgO}+\mathrm{FeO}+\mathrm{MnO}$

$\mathrm{C}=$ core

$\mathrm{M}=$ margin

Amphibole is ubiquitous to all rock types in both the main body and the second body. In unsheared varieties the amphibole is commonly zoned from a brown to pale green pleochroic core to a pale green to colourless pleochroic margin. Analyses from five zoned amphiboles in a variety of rock types are given in Table 3. Amphibole compositions range from tschermakite cores to magnesiohornblende margins in metagabbroic rock types and from magnesio-hornblende cores to actinolite or rarely tremolite margins in ultramafic rock types. The amphibole compo- sitions strongly reflect the composition of the host rock coupled with an overprinting due to metamorphism. Cores of zoned amphiboles commonly lie parallel to the regional lineation, indicating their metamorphic origin and thus demanding a metamorphic origin for the zonation. A detailed discussion of the varying amphibole chemistry, the chemical zonation, the relationship to whole rock chemistry and the possible effects of metamorphic grade is given by Thompson (1978).

In metagabbroic rock types, plagioclase is commonly zoned, both when occurring as 
Table 4. Microprobe analyses of Vakkerlien zoned plagioclases.

\begin{tabular}{|c|c|c|c|c|c|c|c|c|c|c|}
\hline \multirow{3}{*}{ Sum } & \multicolumn{6}{|c|}{ Coarse Grains } & \multicolumn{4}{|c|}{ Recrystallized Grains } \\
\hline & \multicolumn{2}{|c|}{76 Vs98 } & \multicolumn{2}{|c|}{$76 \mathrm{Vc} 44-2$} & \multicolumn{2}{|c|}{$77 \mathrm{~V} 2 \mathrm{~S} 36$} & \multicolumn{2}{|c|}{$76 \mathrm{Vs} 98$} & \multicolumn{2}{|c|}{$76 \mathrm{Vs} 91$} \\
\hline & $\mathrm{C}$ & $\mathrm{R}$ & $\mathrm{C}$ & $\mathrm{R}$ & $\mathrm{C}$ & $\mathrm{R}$ & $\mathrm{C}$ & $\mathrm{R}$ & $\mathrm{C}$ & $\mathrm{R}$ \\
\hline $\mathrm{SiO}_{2}$ & 54.57 & 61.35 & 53.17 & 60.5 & 56.54 & 58.34 & 58.95 & 60.13 & 55.99 & 58.02 \\
\hline $\mathrm{Al}_{2} \mathrm{O}_{3}$ & 28.59 & 24.06 & 28.57 & 23.94 & 27.72 & 26.38 & 25.17 & 23.77 & 26.17 & 24.82 \\
\hline $\mathrm{CaO}$ & 11.9 & 5.97 & 12.27 & 6.17 & 10.19 & 8.8 & 7.55 & 6.28 & 9.41 & 7.73 \\
\hline $\mathrm{Na}_{2} \mathrm{O}$ & 4.93 & 8.26 & 5.74 & 9.59 & 6.08 & 7.05 & 8.79 & 10.16 & 7.73 & 9.1 \\
\hline Sum & 99.99 & 99.64 & 99.75 & 100.2 & 100.53 & 100.57 & 100.46 & 100.34 & 99.3 & 99.67 \\
\hline \multicolumn{11}{|l|}{$\mathrm{At}^{0} \%$} \\
\hline $\mathrm{Si}$ & 2.457 & 2.73 & 2.423 & 2.7 & 2.522 & 2.589 & 2.634 & 2.689 & 2.547 & 2.622 \\
\hline $\mathrm{Al}$ & 1.52 & 1.262 & 1.534 & 1.259 & 1.458 & 1.38 & 1.326 & 1.253 & 1.403 & 1.322 \\
\hline $\mathrm{Ca}$ & 0.575 & 0.285 & 0.599 & 0.295 & 0.487 & 0.418 & 0.361 & 0.301 & 0.459 & 0.374 \\
\hline $\mathrm{Na}$ & 0.431 & 0.712 & 0.507 & 0.83 & 0.526 & 0.607 & 0.762 & 0.881 & 0.682 & 0.797 \\
\hline $\mathrm{O}$ & 8 & 8 & 8 & 8 & 8 & 8 & 8 & 8 & 8 & 8 \\
\hline CATSUM & 4.983 & 4.989 & 5.063 & 5.085 & 4.993 & 4.995 & 5.083 & 5.124 & 5.091 & 5.115 \\
\hline$\%$ An & 57 & 29 & 54 & 26 & 48 & 41 & 32 & 25 & 40 & 32 \\
\hline
\end{tabular}

$$
\mathrm{C}=\text { core }
$$

$$
\mathrm{R}=\mathrm{rim}
$$

large $0.5 \mathrm{~mm}$. grains and as small recrystallized grains $(<0.1 \mathrm{~mm})$. Analyses from five representative samples are given in Table 3 , showing a maximum variation from cores of An 57 to margins of An 29. The degree of zonation is highly variable and is most marked in samples with a high $\mathrm{CaO}$ content, which are also characterized by calcite, clinozoisite, rutile mantled by sphene and a high $\mathrm{CaO}$ content of amphiboles.

With the exception of the mantling of rutile by sphene, no other mineral zonation or mineral reaction rims were discovered. Mafic minerals, biotite, chlorite and talc were found to be strongly compositionally controlled by the whole rock composition (Thompson, 1978).

Detailed petrographic work and the determination of mineral chemistry have failed to locate any diagnostic mineral assemblages or invariant reactions to characterize the metamorphic grade. Mineral zonation appears to reflect changing $\mathrm{P}-\mathrm{T}$ conditions, although it is not clear whether this is a retrogressive event or a separate second lowergrade event. Both grades are tentatively placed in the upper greenschist to upper amphibolite grade (Thompson, 1978) consistent with the grade assigned to other areas in the vicinity of Kvikne (Rui, 1973; Nilson and Mukherjee, 1974).

\section{The Vakkerlien sulfide body}

The Vakkerlien sulfide body occupies an approximately central position along the axis of the main metagabbro body. Generally it compares in shape to the main body (Fig. 4) and pinches and swells along its length. A variety of sulfide types are exhibited, hosted both by metagabbroic and ultramafic rock types. The first sulfide type, designated massive vein sulfide, constitutes up to $50 \%$ of the mineralization, occurring as discrete veins varying from $2 \mathrm{~cm}$. to $30 \mathrm{~cm}$. in width. The veins commonly cut through the host rock carrying angular randomly oriented clasts and are marginally discordant to the host rock foliation. The second sulfide type, stringer sulfide, is essentially a variant of the above type. Stringer sulfide constitutes less 
than $20 \%$ of the mineralization and is restricted to highly sheared rock types. Sulfides occur as stringers and shears less than $1 \mathrm{~cm}$. in width, both concordant and discordant to foliations, cutting these with angles as high as $75^{\circ}$. Massive vein sulfide can grade into stringer sulfide with increasing host rock deformation. The final sulfide type, disseminated sulfide, constitutes approximately $30 \%$ of the mineralization. This type is characterized by disseminated sulfides interstitial to metagabbro or ultramafic silicates and varying in proportions from $5-40 \%$ sulfide. The host rock type for disseminated sulfides is consistently non-foliated and apparently undeformed.

\section{Sulfide petrography and chemistry}

All the major sulfide phases are ubiquitous to the three sulfide types, although the modal proportions are highly variable both between and within these types. Disseminated sulfide is the most compositionally uniform sulfide type. The most common phases are pyrrhotite and pentlandite in modal proportions varying from 10:1 respectively to $3: 1$. Chalcopyrite is the other common sulfide showing a completely non-uniform distribution. Generally chalcopyrite constitutes approximately $10 \%$ of the sulfide, although it may reach $90 \%$ in some stringers. Pyrite is present in most samples, and it is estimated to constitute a maximum of $5 \%$ of the sulfides. Accessory gersdorffite and violarite are present, the latter occurring as an alteration product of pentlandite.

Pyrrhotite generally forms large uniform grains with rare pentlandite exsolution flames eminating from fractures, grain boundaries and twins. Typical pyrrhotite analyses, obtained by the microprobe techniques previously described, are given in Table 5. The type of pyrrhotite (monoclinic or hexagonal) was investigated using magnetic colloids. This indicated the predominance of monoclinic varieties with the exception of a few samples containing hexagonal pyrrhotite. The type of pyrrhotite is indicated in Table 5 . Monoclinic pyrrhotites are seen to contain more than 1 wt. $\%$, Ni, ranging up to 3.05 wt. $\% \mathrm{Ni}$, anomalously high when compared to the nickel contents of pyrrhotites reported from other nickel sulfide localities (Blatt, 1972; Harris and Nickel, 1972). Hexagonal pyrrhotites, however, contain a more typical value, less than 0.31 wt. $\% \mathrm{Ni}$. A considerable increase in the abundance of pentlandite exsolution flames was noted in the hexagonal pyrrhotites, relative to the monoclinic pyrrhotites, in a proportion approximately equivalent to that expected if monoclinic pyrrhotite containing 3 wt. $\% \mathrm{Ni}$ exsolved pentlandite until it contained 0.3 wt. $\%$ Ni. No known mechanism can adequately explain the above observations, although it may be postulated that local removal of sulfur resulted in the formation of hexagonal pyrrhotite with a consequent increased ease of nucleation of pentlandite. Whatever the mechanism postulated, it must have occurred below $200^{\circ} \mathrm{C}$ as experimental studies (Misra and Fleet, 1973; Craig, 1973) indicate on ironrich Mss containing 10 wt. $\%$ Ni at $200^{\circ} \mathrm{C}$.

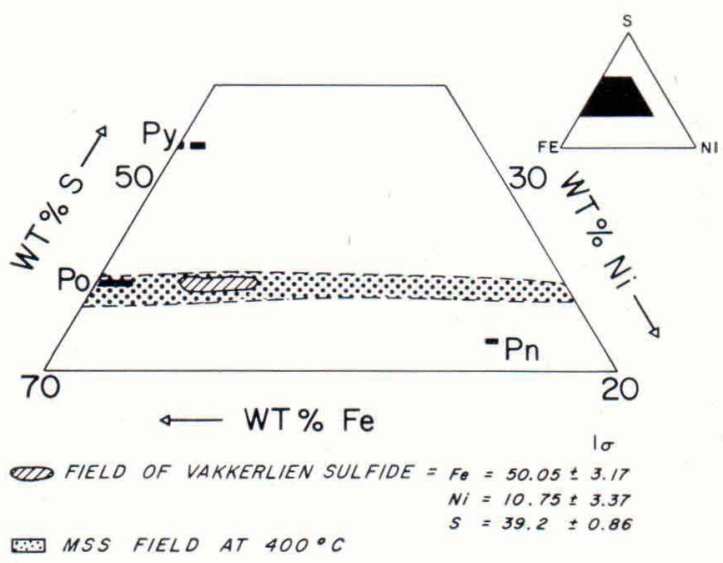

Fig. 7. The composition of Vakkerlien sulfide and individual sulfide phases projected from chalcopyrite onto a Fe-Ni-S diagram. 
Table 5. Microprobe analyses of sulfide phases from the Vakkerlien mineralized zone.

\begin{tabular}{|c|c|c|c|c|c|c|c|c|c|c|}
\hline \multirow{3}{*}{$\begin{array}{l}\text { Sample } \\
\text { Profile }\end{array}$} & \multicolumn{8}{|c|}{ PYRRHOTITE } & & \\
\hline & \multicolumn{2}{|c|}{$77 \mathrm{Vp} 34 \mathrm{~A}$} & \multicolumn{2}{|c|}{$76 \mathrm{Vc} 17$} & \multicolumn{2}{|c|}{$76 \mathrm{Vc} 35$} & \multicolumn{2}{|c|}{$76 \mathrm{Vc} 45$} & \multicolumn{2}{|c|}{$76 \mathrm{Vc} 52$} \\
\hline & 350 & 350 & 550 & 550 & 750 & 750 & 1050 & 1050 & 1150 & 1150 \\
\hline $\mathrm{Fe}$ & 57.16 & 58.26 & 58.2 & 58.21 & 58.77 & 58.56 & 57.28 & 57.25 & $61.71^{\mathrm{H}}$ & $60.6^{\mathrm{H}}$ \\
\hline $\mathrm{Ni}$ & 3.05 & 2.41 & 1.92 & 1.85 & 1.46 & 1.4 & 2.47 & 2.64 & 0.28 & 0.31 \\
\hline $\mathrm{S}$ & 39.46 & 39.3 & 39.04 & 39.5 & 40.53 & 39.23 & 39.44 & 39.44 & 38.78 & 39.48 \\
\hline Sum & 99.67 & 99.97 & 99.16 & 99.56 & 100.76 & 99.19 & 99.19 & 99.33 & 100.79 & 100.39 \\
\hline
\end{tabular}

$\mathrm{H}=$ Hexagonal pyrrhotite, all other samples are monoclinic.

PENTLANDITE

\begin{tabular}{lcccc}
\hline Sample & $76 \mathrm{Vc} 17$ & $76 \mathrm{Vc} 35$ & $76 \mathrm{Vc} 45$ & $76 \mathrm{Vc52}$ \\
\hline $\mathrm{Fe}$ & 28.11 & 29.27 & 28.75 & 29.78 \\
$\mathrm{Co}$ & 0.75 & 0.21 & 0.43 & 0.67 \\
$\mathrm{Ni}$ & 37.86 & 37.0 & 38.26 & 36.75 \\
$\mathrm{~S}$ & 33.16 & 32.92 & 33.23 & 33.4 \\
\hline Sum & 99.88 & 99.4 & 100.66 & 100.59
\end{tabular}

PYRITE

All results are averages of two analyses

\begin{tabular}{lrcc}
\hline Sample & $76 \mathrm{Vc} 35$ & $76 \mathrm{Vc} 45$ & $76 \mathrm{Vc52}$ \\
\hline $\mathrm{Fe}$ & 44.73 & & \\
$\mathrm{Ni}$ & 1.96 & 44.2 & 46.4 \\
$\mathrm{~S}$ & 53.77 & 53.1 & 0.0 \\
Sum & 100.46 & 100.04 & 53.41 \\
\hline
\end{tabular}

Thus, pyrrhotite with $1-3$ wt. $\% \mathrm{Ni}$ is likely to be in equilibrium with pentlandite at some temperature below $200^{\circ} \mathrm{C}$.

Pentlandite occurs predominantly as coarse, blocky grains and rare exsolution flames in pyrrhotite. Pentlandite analyses are shown in Table 5, again indicating a high nickel content for this assemblage when compared to the data of Harris and Nickel (1972). Cobalt, in contrast, is generally low.

Pyrite appears to be largely secondary, replacing pyrrhotite and inheriting the high nickel content (Table 5). Chalcopyrite was found to be essentially stoichiometric.

The $\mathrm{Ni}, \mathrm{Cu}$ and $\mathrm{S}$ content of 156 samples, analysed by A/S Sulfidmalm, have been normalized to massive sulfide, assuming sul- fide compositions typical of the Vakkerlien sulfides. The resultant composition has been projected from chalcopyrite onto the Fe-Ni-S system (Fig. 7) in addition to the composition of the sulfide phases. The full range of normalized ore compositions fall within the range of the continuous Mss at $400^{\circ} \mathrm{C}$ (Naldrett et al., 1967). In spite of uncertainties regarding metamorphic conditions, it is probable that the temperature exceeded $400^{\circ} \mathrm{C}$ throughout metamorphism. All pentlandite and pyrite would, therefore, have been in solid solution in Mss during metamorphism, and textures observed for these minerals have evolved during the cooling following metamorphism. The approximate average copper content is 4 wt. $\%$ in massive sulfide. 


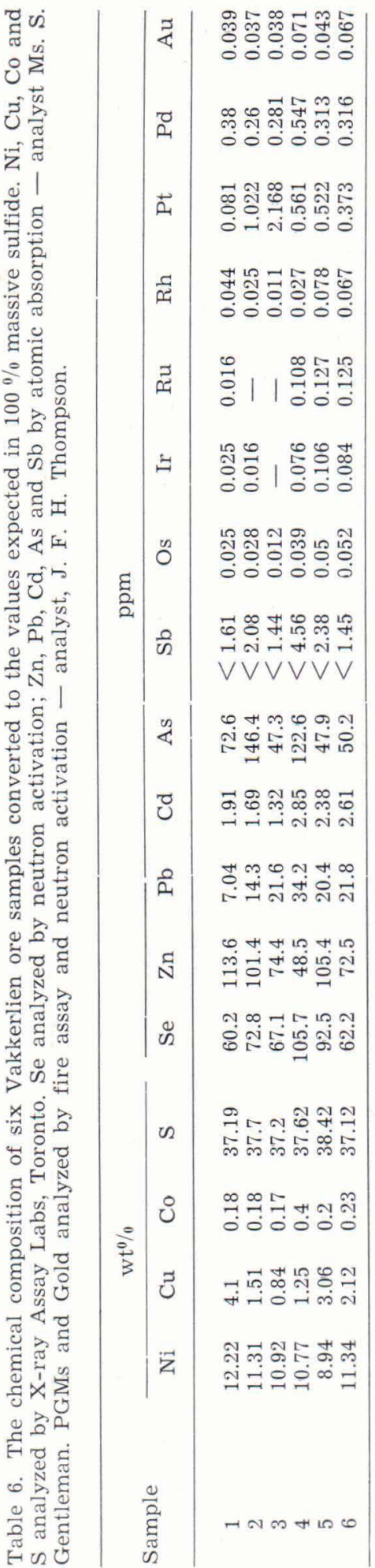

Experimental evidence (Yund and Kullerud, 1966; Moh and Kullerud, 1963; and McQueen, 1979) suggests that this amount of copper could not exist in solid solution in Mss and that a separate Iss phase must have existed during metamorphism. It is possible that selective mobilization of this phase during metamorphism and deformation is responsible for the highly variable copper distribution.

\section{Sulfide Ore Chemistry}

Six sulfide-bearing samples have been analyzed for 17 elements by a variety of techniques. $\mathrm{Ni}, \mathrm{Cu}, \mathrm{Co}, \mathrm{Zn}, \mathrm{Pb}, \mathrm{Cd}, \mathrm{As}$, and $\mathrm{Sb}$ were determined by atomic absorption; $\mathrm{S}$ by titration; Se by neutron activation, and the platinum group elements and gold by chemical pre-concentration and neutron activation according to the technique described by Hoffman et al. (1978). Results from these analyses have been recalculated to express the concentration expected in $100 \%$ sulfide ore and are shown in Table 6 . The first three samples are massive vein sulfide and the second three samples are disseminated sulfide.

The high sulfide nickel content and the variable copper content are apparent. Naldrett and Cabri (1976) correlated the wt. $\%$ $\mathrm{MgO}$ of the parent silicate liquid with the $\mathrm{Cu} / \mathrm{Cu}+\mathrm{Ni}$ ratio of the sulfides. For a gabbroic magma, a $\mathrm{Cu} / \mathrm{Cu}+\mathrm{Ni}$ ratio of 0.5 or more is anticipated. The average Vakkerlien sulfides show a $\mathrm{Cu} / \mathrm{Cu}+\mathrm{Ni}$ ratio of 0.3 , while the individual samples shown in Table 6 all have ratios of less than 0.3 . Although no silicate liquid composition can be identified for Vakkerlien, the range and proportions of rock types would suggest an initial gabbroic magma. The sulfide composition, however, indicates that either the parental magma was more mafic than indicated or the sulfide composition has been modified during metamorphism. Thompson (1978) suggests a mechanism for the release of silicate nickel 


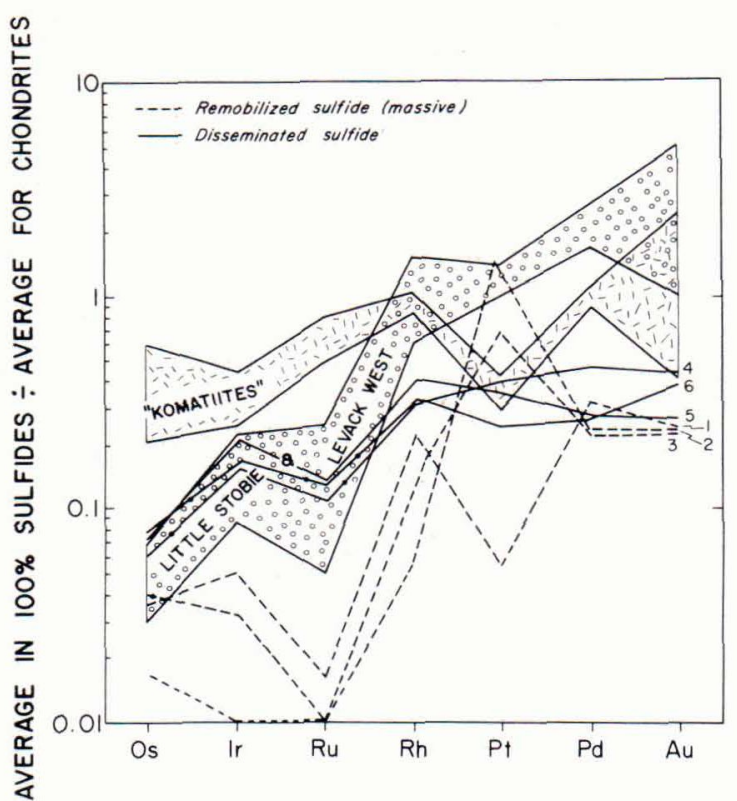

Fig. 8. A plot of the PGE and Au contents of six Vakkerlien sulfide-bearing samples relative to an arbitrary average chondrite content. The fields of three Sudbury ore bodies, Little Stobie \#1 and 2 and Levack West, and three komatiite-hosted ore bodies, Kambalda, Mt. Edwards and Langmuir, are shown for comparison.

contained in igneous olivines during metamorphism, with uptake of this nickel by the sulfides consequently modifying their composition.

No particular difference is apparent for most of the elements between massive vein sulfide and disseminated sulfide. The platinum group elements, however, show a marked difference between the two sulfide types. This difference is demonstrated in Fig. 8 , a plot of the metal content of the sulfide divided by an arbitrary chondrite metal content used by Naldrett et al. (1979) for all the platinum group elements. All three disseminated sulfide samples have similar trends, while trends for the samples of massive vein sulfide, while erratic, are strongly depleted in Os, Ir and Ru. A variety of evidence exists to suggest that $\mathrm{Os}$, Ir and $\mathrm{Ru}$ are highly immobile, but Rh, Pt, Pd and Au are clearly mobile (Fucks and Rose, 1974; Cousins and
Vermaak, 1976; Stumpfl and Tarkian, 1976; Travis et al., 1976). Thus, the difference in trends exhibited by the ore types suggests that massive vein sulfide have been remobilized, possibly by hydrothermal solutions during metamorphism, from original disseminated sulfides. One anomalous point in the Vakkerlien data is the similar levels of $\mathrm{Pd}$ and $\mathrm{Au}$ in all samples. In the studies referred to above, these metals show mobility to an even greater extent than $\mathrm{Pt}$ and $\mathrm{Rh}$. It is possible that their high mobility allowed continued transportation and homogenization of these elements once the massive sulfide had been emplaced and the particular conditions responsible for large scale sulfide remobilization had relaxed.

The shaded areas on Fig. 8 represent the trends obtained from three Sudbury nickel sulfide deposits and those obtained from three Archaean komatiite-hosted nickel sulfide deposits (Naldrett et al., 1979). The trend of the Vakkerlien disseminated sulfides falls within the Sudbury trend for Os, Ir and $\mathrm{Ru}$, although it is relatively depleted in $\mathrm{Rh}, \mathrm{Pt}$, $\mathrm{Pd}$ and $\mathrm{Au}$. The relative increase from Os to $\mathrm{Au}$ across the diagram for the Vakkerlien disseminated sulfides is, however, typical of the gabbroic-hosted sulfide deposits rather than the ultramafic komatiite-hosted deposits. Thus, this data supports the inferred gabbroic host magma with the effect of metamorphism being reflected in the difference between the two sulfide types.

\section{Structure}

All schist types in the Vakkerlien area show a characteristic lamination or banding, producing a clear foliation. This foliation generally dips gently between $5^{\circ}$ and $10^{\circ}$ to the southeast. At least two temporally distinct, but spatially coincident, deformation phases involving isoclinal folding and extreme flattening have produced the observed 
foliation. Each phase may have transposed the previous foliation into the subsequent foliation orientation or have involved a similarly oriented stress field. The phases of isoclinal folding are delineated by phases of quartz veining showing varying degrees of deformation in single outcrops. Trondhjemite intrusion transgressed the closing stages of isoclinal folding. Some trondhjemite bodies are clearly foliated, while the majority of the bodies are quite massive.

The foliation commonly undulates forming symmetrical folds with a wave length greater than 5 metres. The axes of these folds dip gently to the southeast, coinciding with the isoclinal fold hinges and indicating a final weak phase of deformation parallel to the major isoclinal phases.

Isoclinal fold hinges form a prominent regional lineation parallel to the local development of a mineral lineation. The average lineation direction from 57 readings in the Vakkerlien area was $113^{\circ} \pm 12.7^{\circ}$, plunging at approximately $5^{\circ}$. This lineation is essentially parallel to the Vakkerlien metagabbro bodies.

A final phase of deformation has been delineated in the northern part of the Vakkerlien grid. This phase is quite different from those previously described and involves tight upright kink bands trending north-south and overturned to the west.

\section{A deformation model for the Vakkerlien metagabbros}

Early phases of quartz veining suffered at least two phases of isoclinal folding. During this deformation, the competency difference between the schists and the quartz veins commonly resulted in attenuation of quartz veins in isoclinal fold limbs and isolation of the fold hinges. Quartz is commonly found occurring in isolated fold hinges throughout the Vakkerlien area. The deformation style

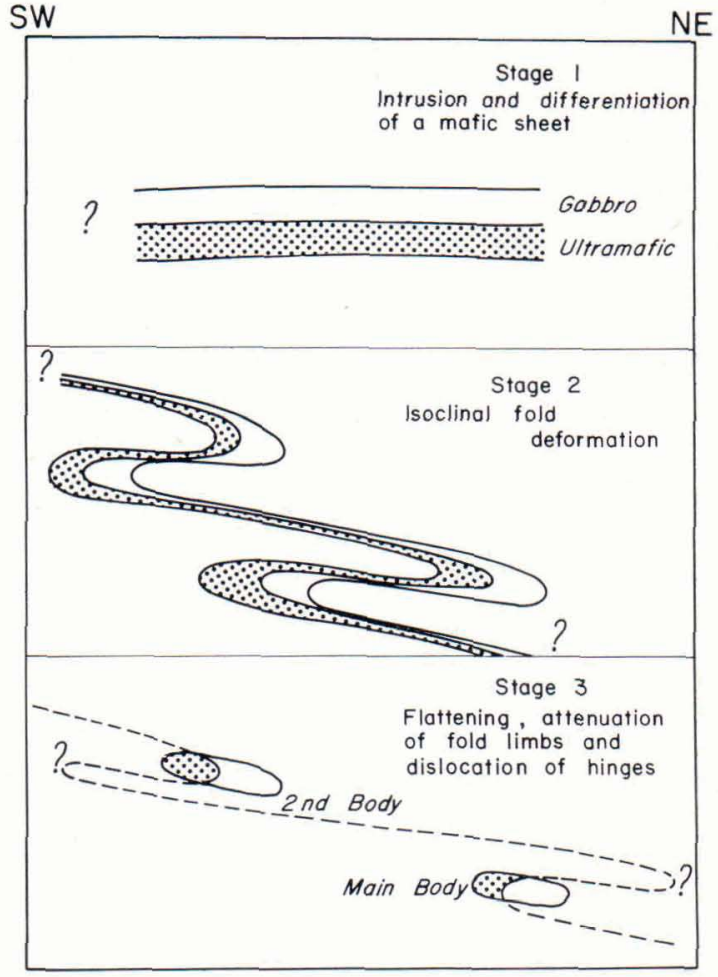

Fig. 9. A deformation model for the formation of the separate Vakkerlien metagabbro bodies.

in the Vakkerlien metagabbros has involved intense deformation on localized shear zones with the preservation of comparatively undeformed regions between these zones. Crosscutting shear zones are common, but it is not possible to correlate the resultant complex foliation with the regional isoclinal fold phases. It seems likely, however, that the Vakkerlien metagabbros have suffered extensive isoclinal folding if not all the events demonstrated regionally. As such, it is suggested that isoclinal folding of a differentiated gabbro sheet would result in attenuation of the limbs and isolation of the fold hinges in a manner analogous to that of the quartz veins. This model is shown in Fig. 9 and has the attraction of explaining the distribution of rock types within the two bodies.

Magmatic sulfide ore bodies commonly occupy a basal position in mafic igneous com- 
plexes. It is, thus, important to consider to what extent the present centrally located mineralized zone is the result of deformation and metamorphism. Deformation studies on sulfides (Clark and Kelly, 1973) and sulfides with silicates (Zolotukhin et al., 1972) have indicated the relative ease with which sulfides can behave plastically. Both studies were carried out at relatively low $\mathrm{P}$ and $\mathrm{T}$ conditions, but it is likely that sulfides would continue to be more plastic than silicates at elevated $\mathrm{P}$ and $\mathrm{T}$ conditions. The Vakkerlien area has clearly been plastically deformed and, thus, it can be assumed that the Vakkerlien sulfides were potentially more mobile under these conditions. No deformation model, however, can adequately explain the present distribution of sulfides if an original basal position is envisaged. Massive vein sulfide and stringer sulfide show clear evidence of remobilization, the sulfide chemical data suggesting that metamorphic fluids may have been active in this process. Local plastic remobilization may also have occurred, particularly in highly discordant sulfide stringers. Disseminated sulfides have clearly been recrystallized in that they now occupy an interstitial position to metamorphic silicates, presumably originating as sulfide interstitial to igneous silicates. Their position, however, in essentially undeformed metagabbro and ultramafic, suggests that large scale remobilization has not affected these sulfides and that the deformation style within the metagabbro, the majority of the strain being absorbed on discrete shear zones, has preserved the disseminated sulfide in a relatively primary position. Thus, it is suggested that the highly unusual position of the sulfides reflects an original igneous concentration with additional remobilization of some sulfide in deformed metagabbro and ultramafic into the fold hinge containing the main metagabbro body. The fact that the second metagabbro body, argued to be lying in a fold hinge, is barren of sulfides also suggests that local igneous concentration of sulfide existed prior to deformation and metamorphism and that deformation alone is not responsible for the central location of sulfides within the main body.

\section{Conclusions}

A mafic sheet was intruded into the Gula group and differentiated in place. Although metamorphosed volcanics are present in the area, geochemical evidence does not clearly support a petrogenetic connection. A connection is, however, not ruled out as it is not possible to quantify the effects of metamorphism on the composition of the volcanics and the Vakkerlien bodies.

The Vakkerlien bodies clearly suffered severe deformation. Conclusive correlation with regional deformation events is, however, hindered by the inhomogeneous deformation style of the metagabbro bodies. Comparison with deformed quartz veins suggests a deformation model for the mafic sheet involving isolation of individual bodies in isoclinal fold hinges, which consequently lie parallel to the regional lineation. This model explains the position and orientation of the bodies and the distribution of rock types within them. No igneous mineralogy is preserved. Zonation of amphiboles and plagioclases indicate a complex, possibly two-phase metamorphic history, although it is not possible to define precise $\mathrm{P}$ and $\mathrm{T}$ conditions.

Pyrrhotite, pentlandite and chalcopyrite are the major sulfide mineral phases in the mineralized zone. Pyrrhotite phases and compositions reflect a complex low temperature history. Three sulfide types are defined, two of which were clearly remobilized during deformation. The third sulfide type may have remained in place, and it is suggested that the mineralized zone occupies a partially 
primary position with additional concentration during deformation.

Acknowledgements - The first author gratefully acknowledges A/S Sulfidmalm who initiated the research project and provided support for field work. In particular, Dr. J. B. Gammon is acknowledged for support and valuable contribu- tions to the study. The majority of the analytical studies were performed at the University of Toronto and thanks are due to Mrs. M. Gorton and E. Hoffman and Ms. S. Gentleman for their assistance. Prof. A. J. Naldrett is acknowledged for critically reading the manuscript. Financial support was provided by an NRC Operating Grant No. A4244, A/S Sulfidmalm and a Rhodes Scholarship Trust Award to the first author.

\section{References}

Blatt, A. P. (1972) Nickel distribution in hexagonal and monoclinic pyrrhotite. Can. Min. 11, 829897.

Clark, B. R. and Kelly, W. C. (1973) Sulfide deformation studies: I. Experimental deformation of pyrrhotite and sphalerite to 2000 bars and $500^{\circ}$ C. Econ. Geol. 68, 332-352.

Cousins, V. A. and Vermaak, C. F. (1976) The contribution of Southern African ore deposits to the geochemistry of platinum group metals. Econ. Geol. 71, 287-305.

Craig, J. P. (1973) Pyrite-pentlandite assemblages and other low temperature relations in the Fe-Ni-S system. Am. Jour. Sci. 273, 496-510.

Fucks, W. A. and Rose, A. W. (1974) The geochemical behaviour of platinum and palladium in the weathering cycle in the Stillwater Complex, Montana. Econ. Geol. 69, 332-346.

Gale, G. H. and Roberts, D. (1974) Trace element geochemistry of Norwegian Lower Palaeozoic basic volcanics and its tectonic implications. Earth Planet. Sci. Lett. 22, 380-390.

Gee, D. G. (1975 a) A tectonic model for the central part of the Scandanavian Caledonides. Am. Jour. Sci. 275, 468-518.

- $(1975$ b) A geotraverse through the Scandinavian Caledonides - Ostersund to Trondheim. Sveriges Geol. Unders., Series C, No. 717, 66 pp.

- (1978) Nappe displacement in the Scandinavian Caledonides. Tectonophysics 47, 393-419.

- and Zachrisson, E. (1974) Comments on stratigraphy, faunal provinces and structure of the metamorphic allochthon, central Scandinavian Caledonides. Geol. Fören. Stockholm Förh 96, $61-66$.

Guezou, J.-C., Poitout, M.-J. and Santarelli, N. (1972) Le complex de Trondheim et son soubas- sement dans la region de Lesja Dombås (Oppland, Norvège centrale). Sci. de la Terre 17, $273-287$.

Harris, D. C. and Nickel, E. H. (1972) Pentlandite compositions and associations in some mineral deposits. Can. Min. 11, 861-878.

Hoffman, E. L., Naldrett, A. J., Van Loon, J. C., Hancock, R. G. V. and Marson, A. (1978) The determination of all the platinum group elements and gold in rocks and ores by neutron activation analysis after preconcentration by a nickel sulfide fire assay technique. Anal. Chim. Acta 102, 157-166.

Misra, K. C. and Fleet, M. E. (1973) The chemical composition of synthetic and natural pentlandite assemblages. Econ. Geol. 68, 518-539.

McQueen, K. G. (1979) Experimental heating and diffusion effects in $\mathrm{Fe}-\mathrm{Ni}$ sulfide ore from Redross, Western Australia. Econ. Geol. 74, 140148.

Moh, G. H. and Kullerud, G. (1963) The Cu-Ni-S system. Carnegie Inst. Washington Year Book $62,189-192$.

Naldrett, A. J. and Cabri, L. (1976) Ultramafic and related mafic rocks: Their classification and genesis with special reference to the concentration of nickel and platinum group elements. Econ. Geol. 71, 1131-1158.

- , Craig, J. R. and Kullerud, G. (1967) The central portion of the Fe-Ni-S system and its bearing on pentlandite exsolution in ironnickel sulfide ores. Econ. Geol. 62, 826-847.

- ,Hoffman, E. L., Green, A. H., Chou, C.-L., Naldrett, S. R. and Alcock, R. A. (1979) The composition of nickel sulfide ores with particular reference to their content of PGE and Au. Can. Min. 17, pt. 2 (in press).

Nilson, O. (1974) Mafic and ultramafic inclusions 
from the initial (Cambrian?) volcanism in the central Trondheim region, Norway. Nor. Geol. Tidsskr. 54, 337-359.

- and Mukherjee, A. D. (1972) Geology of the Kvikne mines with special reference to the sulfide ore mineralization. Nor. Geol. Tidsskr. $52,151-192$.

Nockolds, S. R. (1941) The Garabal Hill-Glen Fyne igneous complex. Geol. Soc. London Quart. Jour. 96, 451-511.

Norrish ,K. and Hutton, J. T. (1969) An accurate $\mathrm{X}$-ray spectrographic method for the analysis of a wide range of geological samples. Geochim. Cosmochim. Acta 33, 431-453.

Pinna, P. (1973) Étude géologique de Dovrefjell meridional. Thèse, Université Paris, Orsay, $165 \mathrm{pp}$.

Roberts, D. (1967) Structural observations from the Kopperå-Riksgrense area and discussion of the tectonics of Stjørdalen and the N. E. Trondheim region. In Studies in the Trondheim Region, Central Norwegian Caledonides II. Nor. Geol. Unders. 245, 64-120.

- Springer J. and Wolff, F. C. (1970) Evolution of the Caledonides in the northern Trondheim region, central Norway: a review. Geol. Mag. 107, 2, 133-145.

Rohr-Torp, E. (1972) A major inversion of the western part of the Trondheim nappe. Nor. Geol. Tiddskr. 52, 453-458.

Rui, I. S. (1973) Geology and structures of the Røstvangen sulphide deposit in the Kvikne district, central Norwegian Caledonides. Nor. Geol. Tidsskr. 53, 433-442.

- and Bakke, I. (1975) Stratabound sulphide mineralization in the Kjøli area, Røros district,
Norwegian Caledonides. Nor. Geol. Tiddskr. 55, $51-75$.

Stumpfl, E. F. and Tarkian, M. (1976) Platinum genesis: new mineralogical evidence. Econ. Geol. 71, 1451-1460.

Thompson, J. F. H. (1978) The geology of the Vakkerlien nickel deposit, Kvikne, Norway. Unpub. M.Sc. Thesis, University of Toronto.

Travis, G. A., Keays, R. R. and Davison, R. $M$. (1976) Palladium and iridium in the evaluation of nickel gossans in Western Australia. Econ. Geol. 71, 1229-1243.

Wager, L. R. and Deer, W. A. (1939) Geological investigations in east Greenland, Pt. III, Petrology of the Skaergaard intrusion, Kangerdlugssuaq, East Greenland. Med. om Grønland Bd. 105, No. 4, 335 pp.

Walker, F. (1940) Differentiation of the Palisade diabase. Geol. Soc. Am. Bull. 51, 1059-1106.

Wegman, E. (1925) Sur le lambeau de recouvrement de la Gula (Chaine Calédonide Scandinave). Soc. Géol. France, Compte rendu, somm Sci., 158-159.

Wolff, F. C. (1967) Geology of the Meråker area as a key to the eastern part of the Trondheim region. In Studies in the Trondheim Region, Central Norwegian Caledonides II. Nor. Geol. Unders. 245, 123-142.

Yund, R. A. and Kullerud, G. (1966) Thermal stability of assemblages in the Cu-Fe-S system. Jour. Petrology 7, 2239-2244.

Zolotukhin, V. V., Ushakov, G. D. and Ryabov, V. V. (1972) Mechanical activity of sulphide material in massive Noril'sk ores. Doklady Akad. Nauk., U.S.S.R. 216, 91-93.

Manuscript received, September 10, 1979 